\title{
Dönüştürücü ve Etkileşimci Liderlik Tarzı ile Negatif İnovasyon Algısı Arasındaki İlişkiye Yönelik Bir Araştırma ${ }^{1}$
}

\author{
Mutlu TOKMAK \\ J. Yzb. Dr, Jandarma ve Sahil Güvenlik Akademisi, \\ Jandarma ve Sahil Güvenlik Fakültesi, Sosyal Bilimler Bölümü \\ mutlu-tokmak@hotmail.com \\ Orcid ID: https://orcid.org/0000-0002-7428-1322
}

\section{Öz}

İnovasyon, işletmelerin kazançlarını artırmak amacıyla yapılan yenilikleri ve değişiklikleri ifade etmektedir. Bazı yöneticilerde inovasyon uygulamalarının işletme için olumsuzluklar getireceği düşüncesi yer almaktadır. Bu çalışmada, yöneticilerin inovasyon uygulamaları neticesinde işletmeye negatif etkilerinin olacağ1 algısı ile uyguladıkları dönüştürücü ve etkileşimci liderlik tarzları arasındaki ilişkisi araştırılmaktadır.

Çalışmanın amacına yönelik, Bursa ili ve çevresinde faaliyet gösteren 108 Küçük ve Orta Ölçekli İşletme (KOBİ) sahibi ve yöneticisi ile alan araştırması gerçekleștirilmiştir. Alan araştırmasında anket tekniğinden yararlanılmış elde edilen veriler korelâsyon ve tanımlayıcı istatistik analizleri ile değerlendirilmiştir.

Araştırma sonucunda, dönüştürücü liderlik tarzı ile inovasyonun getireceği belirsizlik ve müşteri direnciyle karşılaşılacağına yönelik negatif inovasyon algıları arasında ters yönlü ilişki olduğu tespit edilmiştir. Etkileşimci liderlik tarzının; konum riski algısı, inovasyonun ek maliyet getireceği düşüncesi, müşteri direnci ve personel direnci ile karşılaşılacağına yönelik olumsuz inovasyon algısını arttırdığı sonucuna ulaşılmıştır.

Anahtar Kelimeler: İnovasyon, Negatif İnovasyon Algıs1, Dönüştürücü Liderlik, Etkileşimci Liderlik.

\footnotetext{
${ }^{1}$ Makale Geliş/Kabul Tarihi: 29.04.2019 / 08.08.2019

Künye Bilgisi: Tokmak, M. (2020). Dönüştürücü ve Etkileşimci Liderlik Tarzı ile Negatif Inovasyon Algısı Arasındaki İlişkiye Yönelik Bir Araştırma. Kahramanmaraş̧ Sütçü İmam Üniversitesi Sosyal Bilimler Dergisi, 17 (1), 441-464. DOI: 10.33437/ksusbd.558800
} 


\title{
A Research on the Relationship between Transformer and Interactive Leadership Style and Negative Innovation
}

\begin{abstract}
Innovation refers to innovations and changes made to increase the earnings of enterprises. Some managers think that innovation practices will bring negativity to the enterprise. In this study, the relationship between the perception of executives' negative effects on the business as a result of innovation practices and the transformational and transactional leadership styles they are applying are investigated.

For the purpose of the study, a field survey was conducted with 108 Small and Medium-sized Enterprises (SME's) owners and managers operating in and around Bursa. The data obtained from the survey technique in the field research were evaluated by correlation and descriptive statistical analysis.

As a result of the research, it has been found that there is an inverse relationship between the perception of transformational leadership style and the uncertainty of innovation and negative innovation perception that customer resistance will be encountered. Transactional leadership style; It is concluded that the perception of location risk, the idea that innovation will bring additional cost; increase the perception of negative innovation towards customer resistance and personnel resistance.
\end{abstract}

Keywords: Innovation, Negative Innovation Perception, Transformational Leadership, Transactional Leadership.

\section{GİRIȘ}

İnovasyon, işletmelerin katma değerlerini arttırmak amaciyla gerçekleştirdikleri yenilikler ve değişiklikler olarak değerlendirilmektedir. İnovasyon uygulamaları işletme içerisinde değişikliklere neden olmaktadır. Değişim ile birlikte belirsizliklerin ortaya çıkması ve bu değişikliklerin risk içeriyor olması, inovasyon uygulamalarına karşı olumsuz düşüncelere neden olabilmektedir.

İnovasyon uygulamalarının işletme sahipleri tarafından negatif algılanmalarına yol açabilecek hususlar incelendiğinde; inovasyon uygulamaları neticesinde yöneticilerin mevcut konumlarını kaybetme riskinin olması, inovasyonu yönetememe düşüncesi, belirsizlik algısı, işletme maliyetlerini 


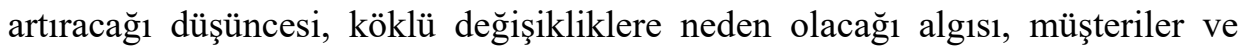
personel tarafından dirençle karşılaşılacağına yönelik algılar gibi olumsuz düşünceler inovasyonun negatif algılanmasına neden olmaktadır (Torun, 2016; 72).

İnovasyon uygulamalarının işletme içerisinde başarıya ulaşmasındaki etkili faktörlerden bir tanesi de uygulanan liderlik tarzıdır. Liderlerin çalışanlarına yönelik davranışları, onlara önderlik etmeleri ve yol gösterici olmaları çalışanların inovasyona bakış açılarını değiştirecektir. Geleneksel liderlik anlayışını benimseyen yöneticilerin olduğu örgütlerde çalışanların da geleneksel yönetim anlayışını benimsemeleri beklenen bir durumdur. Modern yönetim anlayışını benimseyen liderlerin yenilikler konusunda çalışanlarını daha kolay motive edebilecekleri beklenmektedir.

Bu çalışmada işletme içerisinde uygulanan dönüştürücü ve etkileşimci liderlik tarzları ile negatif inovasyon algıları arasında nasıl bir ilişkinin olduğunun ortaya konması amaçlanmaktadır. Geleneksel yönetim anlayışına sahip ve daha kuralcı olan etkileşimci liderliğin hüküm sürdüğü örgütlerde çalışanlarda hangi tür negatif inovasyon algılamalarının daha yoğun olduğu belirlenmeye çalışılmaktadır. Ayrıca, etkileşimci liderlik anlayışına göre daha çağdaş bir anlayışa sahip olan dönüştürücü liderliğin hüküm sürdüğü örgüt çalışanlarında ne tür negatif inovasyon algılarının ortaya çıktığı da araştırmada ulaşılmak istenen sonuçlar arasındadır. Çalışmanın amaçlarına ulaşmak için alan araştırması gerçekleştirilmiştir. Elde edilen veriler tanımlayıcı istatistik ve korelâsyon analizi ile değerlendirilmiştir. Analiz sonuçları ile geçmiş araştırma verilerinin yer aldığ 1 literatürden elde edilen sonuçlar karşılaştırmalı olarak aktarılmaya çalışılmıştır.

\section{KAVRAMSAL ÇERÇEVE}

Bu bölümde dönüştürücü ve etkileşimci liderlik tarzları ile ilgili teorik bilgiler yer almaktadır. Ayrıca inovasyon uygulamalarının olumsuz etkilerinin yer aldığı negatif inovasyon algısı kavramı açıklanmaktadır. İlgili yazında yer alan araştırmalar ve çalışmanın amacına uygun olarak geliştirilen hipotezlere de bu bölümde yer verilmektedir.

\section{Dönüştürücü ve Etkileşimci Liderlik Tarzı}

Lider, bir organizasyon içerisinde yada kişiler arasında ortaya çıkan sorunları çözebilme gücüne sahip olan, örgüt kültürünün oluşmasını sağlayan, yöneten ve gerektiğinde değiştirebilen, insanları bir amaç etrafinda toplayan, sahip olduğu özellikler sayesinde insanlar üzerinde etkisi olan kişidir (Dinçer ve Bitirim, 2007: 61; Mumford vd. 2000: 14; Schein, 2004: 223; Zaccaro vd., 2000: 38). 
Dönüştürücü Liderlik: Organizasyonların karşılaştığı sürekli değişim ortamındaki çevre koşullarına uyum sağlamak amacıyla izlenen etkin bir liderlik tarzı olarak değerlendirilmektedir. (Bass ve Bass, 2008; Turner vd., 2002; Nielsen ve Cleal, 2011: 344). Dönüştürücü liderlik, lider tarafindan önderlik edilen grubun amaçlarına yönelik yeni bir anlayış ortaya koyma ve bu çerçevede takipçilerini harekete geçirme süreci olarak değerlendirilmektedir (K1lıç vd., 2014: 251; Koparal, 2007: 150).

Dönüştürücü lider, örgüt çalışanlarını en önemli kaynağı olarak görmektedir. İnovasyonun gerçekleştirilebilmesi için uygun ortamın oluşturulmasına önem vermektedir. Dönüştürücü lider, ekip çalışanları arasında etkili bir iletişimin olmasını ve üyeler arasındaki paylaşımın sağlanmasını önemsemektedir. Bu tarz liderler, örgüt içerisinde yeni fikirlerin tanıtımı, hedeflerin ortaya konmasını ve inovasyon konusunda örgüt üyelerinin inisiyatif kullanmasını teşvik etmektedir. (Senge vd., 1994; Garcia-Morales vd., 2008: 189), Literatürdeki araştırmalar, teknoloji tabanlı organizasyonlarda, dönüştürücü liderlik yaklaşımının, etkileşimci liderlik yaklaşımına göre, inovasyonu teşvik etmede daha etkili olduğunu göstermektedir. (Gardner ve Avolio, 1998; Jung vd., 2003, 528).

Etkileşimci Liderlik: İngilizce literatürde "transactional leadership" olarak geçen bu kavram, çeşitli kaynaklarda etkileşimci, işlemsel veya transaksiyonel liderlik olarak kullanılmaktadır (Kılıç vd., 2014: 251). Bu liderlik teorisi J.M. Burns tarafından 1970'li yıllarda ortaya atılmıştır. Bass (1985) başta olmak üzere birçok araştırmacı tarafından bu teoriye katkı sunulmuştur. Bu teoride ortaya çıkan temel nokta, lider ve takipçileri arasında işin gerçekleşmesine dayanan karşılıklı ilişki ve işlerin yerine getirilmesi için liderin ortaya koyduğu davranış tarzlarıdır (Koçel, 2014: 695). Etkileşimci lider; takipçilerini beklentileri doğrultusunda oldukça net bir şekilde bilgilendiren ve kendilerinden beklenen performansın yerine getirildiğinde ne tarz bir ödül elde edileceği konusunda takipçilerini aydınlatan liderdir (Bass, 1985: 27). Antonakis ve diğerleri (2003: 265), etkileşimci liderliği, sözleşmeden kaynaklanan yükümlülüklerin yerine getirilmesine dayanan bir değişim süreci, hedef belirleme, denetleme ve ortaya çıkan sonuçları izleme olarak değerlendirmektedir. Etkileşimci liderlik anlayışında, çalışanların belirli bir amacı gerçekleştirmeleri için ödül ve ceza sistemi kullanılmaktadır (Fernandes ve Awamleh, 2004: 66; Odumeru ve Ifeanyi, 2013: 358).

Etkileşimci liderlik tarzında davranış sergileyen yöneticiler yetkilerini daha çok, takipçilerini ödüllendirme ve onların daha fazla çaba göstermelerini sağlamak amacıyla para ve statü verme şeklinde kullanırlar. Bu liderlik tarzının, geçmişten gelen gelenekleri sürdürme ve olumlu davranışların gelecek nesillere aktarılması konusunda pozitif etkileri olmakla birlikte, yaratıc1lık ve yenilik yönünün az olması gibi negatif yönleri de bulunmaktadır (Eren, 2003: 34). 


\section{İnovasyon ve Negatif İnovasyon Algısı}

İnovasyon, işletmelerin kendisini diğer organizasyonlardan farklılaştırabilmesi, rekabet avantajı sağlayabilmesi ve rakiplerine karşı üstünlük elde edebilmesi için, yeni ürünler, hizmetler ve süreçler geliştirmesi olarak tanımlanmaktadır (Baregheh, 2009: 1334). Gamal ve diğerleri (2011) inovasyonu, yeni bir ürünü, hizmeti veya süreç fikrini geliştirerek ticarileştirme ve piyasaya sunarak kazanç elde etme olarak değerlendirmektedir. İnovasyon, ürün, süreç ve iş modelinde niteliksel ve niceliksel anlamda yapılan gelişme ve iyileştirmeler olarak da tanımlanabilir (Zeleny, 2012: 441). İnovasyon, süreç olarak birbirini izleyen farklı aşamalardan meydana gelmektedir. İşletmelerin geleneksel ürün ve hizmet anlayışı ile rekabet ortamında ayakta kalmaları mümkün değildir. Bu durum onların inovasyon konusuna ilgi duymalarını ve ürün ve hizmetlerinde yenilikler yapmalarını zorunlu kılmıştır (Örücü vd., 2011: 59).

Bir organizasyonda inovasyon faaliyetlerinin ortaya çıkmasında ve yönetilmesinde en önemli faktörlerden bir tanesi de inovasyon algılarıdır. İnovasyon algılarına yönelik çalışmalar yapılırken başarılı inovasyon uygulamaları ve inovasyona karşı oluşturulan dirençlerden yola çıkarak pozitif ve negatif inovasyon algıları ortaya koyulabilmektedir (Torun, 2016: 23). Simpson ve diğerleri $(2006,1133)$, yaptıkları araştırmada, yöneticilerin olumsuz inovasyon algılarının olumlu olanlara nazaran daha fazla olduğu sonucu ortaya çıkmıştır. Değişim ve yenilik yaparken, piyasa riski, çalışanlar tarafından gösterilen direnç, maliyetlerdeki artı gibi çok sayıda negatif algının ön planda olduğu görülmüştür. Yöneticilerin inovasyon ile ilgili algılarının pozitif ya da negatif yönde oluşu, inovasyon uygulamalarının başarısında da önemli rol oynamaktadir.

$\mathrm{Bu}$ çalışmada yöneticilerin negatif inovasyon algıları ile liderlik tarzları arasındaki ilişki incelendiğinden, teorik olarak negatif inovasyon algılarına yer verilmektedir.

Torun (2016: 29-36) tarafından yapılan çalışma neticesinde negatif inovasyon algılarını şu şekilde sıralamak mümkündür:

Konum Riski: İnovasyon uygulamaları sonucunda meydana gelebilecek değişim ile birlikte, yöneticilerin organizasyon içerisinde kendi konumlarını kaybedeceği düşüncesinin hâkim olması, inovasyonu olumsuz algılamalarına neden olabilmektedir.

İnovasyonu Yönetememe Algısı: İnovasyon ile birlikte değişim ve yenilik sürecinde yer alan personel, gelecek ile ilgili belirsizlik yaşadıkları durumlarda kendilerine yol gösteren ve güven duyulan bir lider tarafindan idare edilmek 
isterler. Yöneticilerin bu konuda kendilerinde eksiklik görmeleri, inovasyon uygulamalarını olumsuz algılamalarına neden olabilmektedir.

Belirsizlik Algısı: İnovasyon uygulamaları yapıları gereği belirsiz ve riskli faaliyetler olarak algılanmaktadır. Algılanan risk derecesinin yüksek olması, inovasyon uygulamalarının negatif olarak algılamalarına yol açabilmektedir.

Ek Maliyet Algıst: İşletmeler için en önemli inovasyon engellerinden bir tanesi, yapılacak yeniliklerin ve değişikliklerin işletmeye ek maliyet getireceği düşüncesidir. İnovasyona yönelik çalışmalar sonucunda ortaya çıkan başarısızlık riski işletmeler için ek maliyet oluşturmaktadır. Bu durum yöneticiler tarafindan inovasyonun olumsuz algılanmasına yol açabilmektedir.

Köklü Değişiklik Algisl: İnovasyon uygulamaları sonucunda gerek organizasyonel yapıda, gerekse süreçlerde bir takım değişiklikler meydana gelmektedir. Organizasyon yapısı olarak bu değişikliği benimseyebilecek örgüt kültürüne sahip olmayan işletmeler, inovasyona karşı direnç göstermektedirler. $\mathrm{Bu}$ durum organizasyonu yöneten kişiler tarafından, inovasyona karşı olumsuz düşüncelerin oluşmasına neden olabilmektedir.

Müşteri Direnci Alglst: İnovasyon uygulaması ile birlikte yeni ürün ve hizmetlerin müşteri beklentilerini karşılayamayacağı düşüncesi, yöneticilerin inovasyon uygulamalarına yönelik olumsuz duygular beslemesine yol açabilmektedir.

Personel Direnci Alglsl: İnovasyon uygulamaları neticesinde bu süreçten en çok etkilenecek grup işletmenin çalışanlarıdır. Yenilik ve değişime ayak uyduramayacak personelin inovasyona yönelik direnç göstermeleri, yöneticiler açısından da bu sürecin olumsuz değerlendirilmesine neden olabilecektir.

\section{Yazın Taraması ve Araştırmanın Hipotezleri}

Literatürde üniversite çalışanlarına yönelik yapılan bir araştırmada, dönüştürücü liderlik yaklaşımının çalışanların yenilik ve yaratıcılık düzeylerini olumlu yönde etkilediği belirlenmiştir (Akbar, vd., 2015). Gürel (2011) tarafından çalışanlara yönelik yapılan bir araştırmada dönüştürücü liderliğin örgütsel inovasyon üzerinde önemli bir etkisinin olmadığ 1 tespit edilmiştir.

Etkileşimci liderliğin yaratıcılık üzerindeki etkisini inceleyen Telekom çalışanlarına yönelik yapılan bir araştırmada, etkileşimci liderliğin örgütsel yaratıcılık üzerinde pozitif yönde etkisinin olduğu tespit edilmiştir (Hussain vd., 2017). Akbar ve diğerleri (2015) tarafından üniversite çalışanlarına yönelik yapılan araştırmada ise, etkileşimci liderliğin çalışanların yaratıcılık ve yenilik düzeylerini olumlu yönde etkilediği belirlenmiştir. 
Literatürdeki liderlik ve inovasyon ile ilgili yapılan araştırmalarda, dönüştürücü liderlik yaklaşımının etkileşimci liderlik yaklaşımına göre inovasyon uygulamaları açısından daha başarılı olduğu tespit edilmiştir (Gardner ve Avolio, 1998; Jung vd., 2003).

Torun (2006: 94) tarafindan, inovasyon algılarının liderlik tarzları üzerindeki etkisinin incelendiği bir çalışmada dönüştürücü liderlerin; ek maliyet algısı, köklü değişiklik algısı ve müşteri direnci algısı gibi olumsuz inovasyon algılarından etkilendikleri sonucuna ulaşmıştır. Aynı çalışmada Torun (2006: 94), konum riski, yönetim zorluğu, belirsizlik algısı ve personel direnci algısının dönüştürücü liderlik üzerinde anlamlı bir etkisinin olmadığını tespit etmiştir. Literatürde, etkileşimci liderlik ile olumsuz inovasyon algısı arasındaki ilişkiyi inceleyen bir çalışmaya rastlanmamıştır.

Dönüştürücü ve etkileşimci liderlik ile negatif inovasyon algısı arasındaki ilişkiyi inceleyen bu çalışmada, araştırmanın amacına uygun olarak aşağıdaki hipotezler geliştirilmiştir.

Hipotez 1: Konum riski negatif inovasyon algısı ile dönüştürücü liderlik ile negatif yönde(H1a) ve etkileşimci liderlik ile pozitifyönde (H1b) bir ilişki vardır.

Hipotez 2: İnovasyonu yönetememe algısı ile dönüştürücü liderlik ile negatif yönde(H2a) ve etkileşimci liderlik ile pozitif yönde (H2b) bir ilişsi vardır.

Hipotez 3: Belirsizlikten kaynaklanan negatifinovasyon algısı ile dönüştürü̈cü liderlik ile negatif yönde(H3a) ve etkileşimci liderlik ile pozitif yönde (H3b) bir ilişki vardır.

Hipotez 4: İnovasyonun ek maliyet getireceği algısı ile dönüştürücü liderlik ile negatif yönde(H4a) ve etkileşimci liderlik ile pozitif yönde (H4b) bir ilişki vardir.

Hipotez 5: Inovasyonun köklü değişikliğe sebep olacağı algısı ile dönüştürücü liderlik ile negatif yönde(H5a) ve etkileşimci liderlik ile pozitif yönde (H5b) bir ilişsk vardır.

Hipotez 6: Müsțteri direnci negatifinovasyon algısı ile dönüşürücü liderlik ile negatifyönde(H6a) ve etkileşimci liderlik ile pozitifyönde (H6b) bir ilişki vardır.

Hipotez 7: Personel direnci negatif inovasyon algısı ile dönüşü̈rücü liderlik ile negatif yönde(H7a) ve etkileşimci liderlik ile pozitif yönde (H7b) bir iliş̧ki vardir.

\section{METODOLOJİ}




\section{Araştırmanın Amacı ve Yöntemi}

$\mathrm{Bu}$ çalışmada yöneticilerin inovasyon getireceği olumsuzluklara yönelik olarak negatif algıları ile dönüştürücü ve etkileşimci liderlik arasındaki ilişkileri incelemek amaçlanmıştır. Bu amaçla Bursa ili ve çevresinde yer alan Küçük ve Orta Büyüklükteki (KOBI) işletme yöneticilerine yönelik alan araştırılması gerçekleştirilmiştir. Alan araştırmasında, nicel araştırma yöntemlerinden anket tekniği kullanılmıştır. Araştırmanın amacına yönelik olarak geliştirilen hipotezlerin test edilmesinde korelasyon analizinden yararlanılmıştır. Ayrıca katılımcıların negatif inovasyon algılarına ve liderlik tarzlarında yönelik görüşlerini belirlemek amaciyla betimsel istatistik verilerine yer verilmiştir.

\section{Araştırmanın Örneklemi ve Veri Toplama Aracı}

Araştırmanın evrenini Bursa ili ve çevresinde bulunan küçük ve orta ölçekli işletmeler oluşturmaktadır. Örneklem $\% 95$ güven seviyesinde ve $\% 5$ güven aralığında belirlenmiştir. Bu amaçla araştırma 108 küçük ve orta ölçekli işletme sahibi ve yöneticisi ile gerçekleştirilmiştir. Araştırmada veri toplama aracı olarak anket kullanılmıştır. Anket formu üç bölümden oluşmaktadır. İlk bölümde katılımcılara yönelik demografik bilgilere yer verilmiştir. İkinci bölümde negatif inovasyon algisını ölçmeye yönelik; konum riski ile ilgili 4 ifade, inovasyonu yönetememe algısına yönelik 3 ifade, inovasyonun belirsizlik getireceği algısına yönelik 3 ifade, inovasyonun işletmeye ek maliyet getireceği algısına yönelik 3 ifade, inovasyonun işletmede köklü değişikliğe neden olacağı algısına yönelik 4 ifade, inovasyonun müşteri direncini artıracağına yönelik 3 ifade, inovasyon uygulamalarının personel direnci ile karşılaşacağı düşüncesine yönelik 4 ifade olmak üzere toplam 24 ifade yer almaktadır. Katılımcıların negatif inovasyon algılarına yönelik ifadelerin hazırlanmasında Torun (2016)' tarafından yapılan araştırmadan yararlanılmıştır. Üçüncü bölümde ise; inovasyon sürecindeki liderlik tarzları ile ilgili olarak dönüştürücü ve etkileşimci liderlik tarzlarına yer verilmiştir. Dönüştürücü ve etkileşimci liderlik tarzları ile ilgili ifadeler Bass ve Avolio (1990) tarafindan yapılan çalışmadan yararlanılarak oluşturulmuştur ve 13 ifadeden oluşmaktadır.

Araştırmaya katılan işletme sahibi ve yöneticilerinin negatif inovasyon algıları ile dönüştürücü ve etkileşimci liderlik tarzlarını belirlemek için 5'li likert ölçeğinden yararlanılmıştır. Ölçek, 1-Kesinlikle Katılmıyorum, 5- Kesinlikle Katılıyorum' u ifade eden 5'li skaladan oluşmaktadır.

\section{Araştırma Bulgularının Değerlendirilmesi}

Alan araştırması sonucu elde edilen veriler IBM SPSS 22.0 istatistik paket programı ile analiz edilmiştir. Araştırma belirlenen hipotezler \%95 güven 
aralığında değerlendirilmiştir. Araştırma sonucu elde edilen verilerin analizinde, tanımlayıcı istatistik yöntemleri ve korelâsyon analizinden yararlanılmıştır.

\section{Demografik Veriler}

Araştırmaya katılan işletme sahibi ve yöneticilere ilişkin demografik özellikler Tablo 1' de gösterilmektedir.

Tablo1. Araştırmaya Katılanların Demografik Özellikleri

\begin{tabular}{|c|c|c|c|}
\hline \multicolumn{2}{|c|}{ Demografik Özellikler } & Frekans & Yüzde (\%) \\
\hline \multirow{4}{*}{ Yaş } & 20-30 yaş arası & 38 & 35.2 \\
\hline & 31-40 yaş arası & 5 & 4.6 \\
\hline & 41-50- yaş aras1 & 44 & 40.7 \\
\hline & 51 Yaş ve üzeri & 21 & 19.4 \\
\hline \multirow{2}{*}{ Cinsiyet } & Erkek & 104 & 96.3 \\
\hline & Kadın & 4 & 3.7 \\
\hline \multirow{3}{*}{ Eğitim Durumu } & Lise & 21 & 19.4 \\
\hline & Önlisans & 37 & 34.3 \\
\hline & Lisans & 50 & 46.3 \\
\hline \multirow{6}{*}{ İşletmede Çalışan Sayısı } & 1-25 Kişi & 17 & 15.9 \\
\hline & 26-50 Kişi & 29 & 26.9 \\
\hline & 51-100 Kişi & 12 & 11.1 \\
\hline & 101-150 Kişi & 15 & 13.9 \\
\hline & 151-249 Kişi & 35 & 32.4 \\
\hline & TOPLAM & 108 & 100,0 \\
\hline
\end{tabular}

Araştırmaya Bursa ile ve çevresinden katılan işletme sahibi ve yöneticilerinin demografik verileri incelendiğinde; 104 (\%96.3)'ü erkek, 4 (\%3.7)'ü kadınlardan oluşmaktadır. 38 (\%35.2) kişi 20-30 yaş aralığında, 5 (\%4.6) kişi 31-40 yaş aralığında, 44 (\%40.7) kişi 41-50 yaş aralığında, 21 (\%19.4) kişi ise 51 yaş üzerindedir. Araştırmaya katılanların öğrenim düzeyleri incelendiğinde ise, 21 (\%19. 4) kişi lise mezunu, 37 (\%34. 3) kişi önlisans mezunu ve 50 (\%46. 3) kişi ise lisans mezunudur. Araştırmaya katılan küçük ve orta büyüklükteki işletmelerde çalışan sayıları incelendiğinde; 17 (\%15. 7) işletmede 1-25 kişi, 29 (\%26. 9) işletmede 26-50 kişi, 12 (\%11. 1) işletmede 51-100 kişi, 15 (\%13. 9) 
işletmede 101-150 kişi, 35 (\%32. 4) işletmede 151-249 kişi arasında çalışan bulunmaktadır.

\section{Güvenilirlik Analizi ve Tanımlayıcı İstatistikler}

Araştırmaya katılan işletme sahibi ve yöneticilerinin negatif inovasyon algılarını belirlemeye yönelik oluşturulan ölçeğin güvenilirliği (Cronbach's Alpha) 0.883 çıkmıştır. Cronbach's Alpha değeri 0.80 'in üzerinde olması ölçeğin yüksek düzeyde güvenilir olduğunu göstermektedir (Kalayc1, 2008: 405). Dönüştürücü ve etkileşimci liderlik tarzlarını belirlemeye yönelik oluşturulan ölçeğin güvenilirliği (Cronbach's Alpha) 0.705 çıkmıştır. Cronbach’s Alpha değeri $0.60 \leq \alpha \leq 0.80$ ise ölçek oldukça güvenilir bir ölçektir (Kalayc1, 2008: 405).

Araştırmada kullanılan ölçeklere yönelik betimsel istatistik verilerine aşağıdaki tabloda yer verilmektedir.

Tablo 2. Negatif İnovasyon Algısı Ölçeği Betimsel İstatistiği

\begin{tabular}{|l||c||c|c|c|c||}
\hline $\begin{array}{l}\text { Negatif İnovasyon Algısı } \\
\text { Ölçeği }\end{array}$ & $\mathbf{N}$ & Min. & Max. & Ort. & S.S. \\
\hline $\begin{array}{l}\text { İnovatif faaliyetlerin } \\
\text { başarısılığı, işletmedeki } \\
\text { konumumu olumsuz } \\
\text { etkileyebilir. }\end{array}$ & 108 & 1.00 & 5.00 & 3.34 & .968 \\
\hline $\begin{array}{l}\text { Uzmanlık alanım inovasyon } \\
\text { olmadı̆̆, için yeni yöneticilere } \\
\text { ihtiyaç duyulması, işletmedeki } \\
\text { konumumu olumsuz } \\
\text { etkileyebilir. }\end{array}$ & 108 & 1.00 & 5.00 & 2.77 & 1.029 \\
\hline $\begin{array}{l}\text { İnovasyon faaliyetleriyle } \\
\text { işletme yapısinda çeşitli } \\
\text { değişikliklerin meydana } \\
\text { gelmesi konumum için risk } \\
\text { oluşturabilir. }\end{array}$ & 108 & 1.00 & 5.00 & 2.73 & 1.029 \\
\hline $\begin{array}{l}\text { İşletme stratejisini değiştirecek } \\
\text { inovasyonlar, yönetim tarzımla } \\
\text { örtüşmeyince konumumu } \\
\text { kaybetme durumuyla karşı } \\
\text { karşıya kalabilirim. }\end{array}$ & 108 & 1.00 & 5.00 & 2.73 & .982 \\
\hline \hline Konum Riski & $\mathbf{1 0 8}$ & $\mathbf{1 . 0 0}$ & $\mathbf{5 . 0 0}$ & $\mathbf{2 . 8 9}$ & $\mathbf{0 . 7 1}$ \\
\hline
\end{tabular}




\begin{tabular}{|c|c|c|c|c|c|}
\hline $\begin{array}{l}\text { İnovasyon faaliyetlerinin } \\
\text { yönetilmesi, gerçekten } \\
\text { uzmanlık isteyen bir konu } \\
\text { olduğu için herkes tarafindan } \\
\text { yönetilemez. }\end{array}$ & 108 & 1.00 & 5.00 & 3.74 & .825 \\
\hline $\begin{array}{l}\text { İnovasyon faaliyetlerini } \\
\text { yönetmek, diğer işlerimi ciddi } \\
\text { şekilde aksatmaktadır. }\end{array}$ & 108 & 1.00 & 5.00 & 2.48 & .779 \\
\hline $\begin{array}{l}\text { İnovasyon sürecini yönetirken } \\
\text { başkalarını ikna etme } \\
\text { konusunda zorlanıyorum. }\end{array}$ & 108 & 1.00 & 5.00 & 3.19 & .672 \\
\hline $\begin{array}{l}\text { İnovasyonu Yönetememe } \\
\text { Algısı }\end{array}$ & 108 & 1.00 & 5.00 & 3.14 & 0.44 \\
\hline $\begin{array}{l}\text { İnovasyon için katlandığımız } \\
\text { maliyetlerin, sağlayacağı } \\
\text { katkılar, işletmeye uzun sürede } \\
\text { dönmektedir. }\end{array}$ & 108 & 1.00 & 5.00 & 3.58 & 672 \\
\hline $\begin{array}{l}\text { İnovasyon faaliyetlerinin, } \\
\text { başarıll olup olmayacağ } \\
\text { belirsizdir. }\end{array}$ & 108 & 1.00 & 5.00 & 3.05 & .980 \\
\hline $\begin{array}{l}\text { İnovasyonlar, süreçteki } \\
\text { belirsizliklerden dolayı, } \\
\text { muhataplar tarafından } \\
\text { genellikle tepkiyle } \\
\text { karş1lanmaktadır. } \\
\end{array}$ & 108 & 1.00 & 5.00 & 2.88 & .872 \\
\hline Belirsizlik Algısı & 108 & 1.00 & 5.00 & 3.17 & 0.54 \\
\hline $\begin{array}{l}\text { İnovasyon faaliyetlerine yapılan } \\
\text { harcamalar, işletmeyi ekonomik } \\
\text { anlamda sıkntıya sokmaktadır. }\end{array}$ & 108 & 1.00 & 5.00 & 2.79 & .737 \\
\hline $\begin{array}{l}\text { İnovasyon faaliyetleri, } \\
\text { maliyetleri artırmaktadır. }\end{array}$ & 108 & 1.00 & 5.00 & 2.97 & .755 \\
\hline $\begin{array}{l}\text { İnovasyon için harcanan } \\
\text { giderleri başka alanlar için } \\
\text { harcamak daha avantajlıdır. }\end{array}$ & 108 & 1.00 & 5.00 & 2.67 & 1.184 \\
\hline Ek Maliyet Algısı & 108 & 1.00 & 5.00 & 2.81 & 0.63 \\
\hline $\begin{array}{l}\text { İnovasyonların köklü } \\
\text { değişikliklere sebep olması, üst } \\
\text { yönetimin inovasyonu } \\
\text { desteklemesini } \\
\text { zorlaştırmaktadır. }\end{array}$ & 108 & 1.00 & 5.00 & 3.38 & .693 \\
\hline
\end{tabular}




\begin{tabular}{|c|c|c|c|c|c|}
\hline $\begin{array}{l}\text { Köklü değişiklikler, iş } \\
\text { süreçlerinin aksamasını } \\
\text { berberinde getirmektedir. }\end{array}$ & 108 & 1.00 & 5.00 & 2.87 & .938 \\
\hline $\begin{array}{l}\text { Köklü değişikliler, işletmedeki } \\
\text { birçok kurulu düzenin işlevini } \\
\text { kaybetmesine sebep olmaktadır. }\end{array}$ & 108 & 1.00 & 5.00 & 3.01 & .717 \\
\hline $\begin{array}{l}\text { İnovasyonların birçok } \\
\text { değişikliğe sebep olması, } \\
\text { işletmenin tüm yapısını } \\
\text { etkilemektedir. }\end{array}$ & 108 & 1.00 & 5.00 & 3.41 & .642 \\
\hline Köklü Değişiklik Algısı & 108 & 1.00 & 5.00 & 3.17 & 0.53 \\
\hline $\begin{array}{l}\text { Ürünlerde yapılan inovasyonlar, } \\
\text { eski (sadık) müşsterilerimizi } \\
\text { işletmeden soğutabilmektedir. }\end{array}$ & 108 & 1.00 & 5.00 & 2.69 & .961 \\
\hline $\begin{array}{l}\text { Müşterilerimiz, alışılmışın } \\
\text { dışındaki ürünlere kolay adapte } \\
\text { olamamaktadır. }\end{array}$ & 108 & 1.00 & 5.00 & 2.96 & .610 \\
\hline $\begin{array}{l}\text { Müşterilerimiz, eski } \\
\text { alışkanlıklarından kolay } \\
\text { vazgeçememektedir. }\end{array}$ & 108 & 1.00 & 5.00 & 3.30 & .615 \\
\hline Müşteri Direnci Algısı & 108 & 1.00 & 5.00 & 2.98 & 0.51 \\
\hline $\begin{array}{l}\text { İ̀sletme çalışanları inovasyonu } \\
\text { kolayca kabul edebilecek bir } \\
\text { yapıdadır. }\end{array}$ & 108 & 1.00 & 5.00 & 3.16 & .959 \\
\hline $\begin{array}{l}\text { Çalışanların inovatif çıtılıara } \\
\text { alışması uzun zaman } \\
\text { almaktadır. }\end{array}$ & 108 & 1.00 & 5.00 & 2.98 & .710 \\
\hline $\begin{array}{l}\text { İ̀şletme çalışanları inovasyona } \\
\text { açık değildirler. }\end{array}$ & 108 & 1.00 & 5.00 & 3.02 & 1.032 \\
\hline $\begin{array}{l}\text { Çalışanlar genellikle inovatif } \\
\text { faaliyetlere destek verecek ufka } \\
\text { sahip değildirler. }\end{array}$ & 108 & 1.00 & 5.00 & 3.02 & .937 \\
\hline Personel Direnci Algisı & 108 & 1.00 & 5.00 & 3.04 & 0.65 \\
\hline
\end{tabular}

Araştırmaya katılan işletme sahibi ve yöneticilerinin negatif inovasyon algılarını belirlemeye yönelik yapılan tanımlayıcı istatistik analizi sonuçları Tablo 2' de gösterilmektedir. Yöneticilerin inovasyon uygulamaları sonucunda işletmedeki konumlarını kaybedeceklerine dair olumsuz algılara yönelik cevaplarının ortalaması 2.89 'dur. 5'li likert ölçeğinde orta değer 3'tür. Orta değer 
ile kıyaslandığında katılımcıların konum riskine yönelik olumsuz algılarının orta değerin altında olduğu görülmektedir.

Katılımcıların inovasyon sürecini yönetemeyeceklerine dair düşüncelerinin yer aldığı ifadelerin ortalama değeri 3.14'tür. Bu oran orta değerin üzerindedir ve katılımcıların inovasyonu yönelik bu kaygıyı taşıdıkları görülmektedir.

İnovasyonun işletmede belirsizliğe neden olacağına dair negatif algı ortalaması ise $3.17^{\prime}$ 'dir $\mathrm{Bu}$ değerde ortanın üzerindedir ve katılımcıların inovasyonu uygulamalarının belirsizlik getirdiğine dair algılarının olduğunu göstermektedir.

İnovasyonun işletme için ek maliyet yaratacağına dair görüşlerin ortalama değeri 2.81 'dir. İnovasyonun işletme maliyetlerine arttıracağına yönelik görüşleri savunan katılımcı sayısı ortanın altındadır.

İnovasyon uygulamalarının işletme içerisinde köklü değişimlere neden olacağ1 yönündeki negatif inovasyon algısı ortalama değeri 3.17' dir. Köklü değişikliğe yönelik negatif algı içerisinde olan katılımcı sayısı orta değerin üzerindedir.

İnovasyonun müşteri direnci ile karşılaşacağına ilişki negatif inovasyon algısı ortalamas 1 2.98' dir. İnovasyon uygulamalarının müşteri direnci ile karşılaşacağına dair düşüncesi olan katılımcı sayısı orta değere çok yakındır.

İnovasyon uygulamaları çerçevesinde personel direnci ile karşılaşılacağını ifade eden katılımcıların ortalama değeri 3.04' tür. Personel tarafından işletme içerisinde yapılacak inovasyon uygulamalarına karşı direnç gösterileceği düşüncesinde olan katılımcı sayısı orta değerin biraz üzerinde çıkmıştır.

Araştırmaya katılan işletme sahipleri ve yöneticilerinin benimsedikleri liderlik tarzlarına ilişkin betimleyici istatistik analizi sonuçları Tablo 3'de gösterilmektedir.

Tablo 3. Dönüştürücü ve Etkileşimci Liderlik Tarzları Ölçeği Betimsel İstatistiği

\begin{tabular}{|l||c||c||c|c|c|}
\hline Liderlik Tarzları & N & Min. & Max. & Ort. & S.S. \\
\hline $\begin{array}{l}\text { Yeni fikirlerin ortaya } \\
\text { çıarılması için çalışanlarımı } \\
\text { cesaretlendiririm. }\end{array}$ & 108 & 1.00 & 5.00 & 4.13 & .762 \\
\hline $\begin{array}{l}\text { Çalışanlarımın inovasyon } \\
\text { sürecindeki görevlerini bilgi ve } \\
\text { yeteneklerine göre düzenlerim. }\end{array}$ & 108 & 1.00 & 5.00 & 4.06 & .681 \\
\hline
\end{tabular}




\begin{tabular}{|c|c|c|c|c|c|}
\hline $\begin{array}{l}\text { İnovasyon sürecinde ortaya } \\
\text { çıkabilecek sorunları } \\
\text { çalışanlarla samimi bir şekilde } \\
\text { paylaşırım. }\end{array}$ & 108 & 1.00 & 5.00 & 3.83 & .690 \\
\hline $\begin{array}{l}\text { İnovasyon sürecinde ortaya } \\
\text { çıan sorunlara çalışanlarla } \\
\text { birlikte çözüm üretmeye } \\
\text { çalışırım. }\end{array}$ & 108 & 1.00 & 5.00 & 3.69 & .729 \\
\hline $\begin{array}{l}\text { İnovasyon sürecinin aksayan } \\
\text { yönleri için çalışanlardan farklı } \\
\text { çözüm yolları üretmelerini } \\
\text { beklerim. }\end{array}$ & 108 & 1.00 & 5.00 & 3.71 & .798 \\
\hline $\begin{array}{l}\text { Çalışanlarımın farklı fikirler } \\
\text { sunmasına izin veririm. }\end{array}$ & 108 & 1.00 & 5.00 & 4.10 & .820 \\
\hline $\begin{array}{l}\text { Çalışanlarımın farklı fikirlerini } \\
\text { samimi şekilde değerlendiririm. }\end{array}$ & 108 & 1.00 & 5.00 & 4.06 & .946 \\
\hline $\begin{array}{l}\text { Çalışanlarıma, inovasyon } \\
\text { konusunda gerekli eğitim } \\
\text { olanaklarını sunarım. }\end{array}$ & 108 & 1.00 & 5.00 & 4.03 & .779 \\
\hline $\begin{array}{l}\text { Çalışanlarıma, inovasyon süreci } \\
\text { için değerli olduklarını } \\
\text { hissettiririm. }\end{array}$ & 108 & 1.00 & 5.00 & 4.05 & .911 \\
\hline Dönüştürücü Liderlik & 108 & 1.00 & 5.00 & 3.96 & 0.53 \\
\hline $\begin{array}{l}\text { İnovasyon sürecinde belirlenen } \\
\text { performans hedeflerine } \\
\text { ulaşıldığında çalışanlarımı } \\
\text { ödüllendiririm. } \\
\end{array}$ & 108 & 1.00 & 5.00 & 4.27 & .731 \\
\hline $\begin{array}{l}\text { İnovasyon sürecinin yönetimini } \\
\text { çalısanlarıma kolaylıkla } \\
\text { bırakırım. }\end{array}$ & 108 & 1.00 & 5.00 & 3.31 & .924 \\
\hline $\begin{array}{l}\text { İnovasyon sürecindeki } \\
\text { sorunlara müdahil olmam için } \\
\text { işlerin yanlış gitmesini } \\
\text { beklerim. }\end{array}$ & 108 & 1.00 & 5.00 & 2.34 & 1.276 \\
\hline $\begin{array}{l}\text { İnovatif davranışlarımızda en } \\
\text { azından geçmiş performans } \\
\text { düzeyimizi korumaya yönelik } \\
\text { hedefler belirlerim. }\end{array}$ & 108 & 1.00 & 5.00 & 3.43 & .788 \\
\hline Etkileşimci Liderlik & 108 & 1.00 & 5.00 & 3.34 & 0.47 \\
\hline
\end{tabular}


Katılımcıların dönüştürücü liderlik tarzına ilişkin ifadelere katılım düzeyleri 3.96'dır. 5'li likert ölçeğinde orta değerin oldukça üzerinde bir değerdir. Etkileşimci liderlik tarzını benimseyen işletme sahibi ve yöneticilerinin ortalama değerleri ise 3.34'tür. Dönüştürücü liderlik tarzını benimseyen işletme sahibi ve yöneticilerinin ortalaması, etkileşimci liderliği benimseyenlere göre daha yüksek düzeydedir.

\section{Araştırma Hipotezlerinin Test Edilmesi}

Çalışmanın amacına yönelik olarak geliştirilen hipotezlerin test edilmesi için korelâsyon analizi kullanılmıştır. Analiz sonucunda elde edilen bilgiler ve hipotezlere ilişkin sonuçlar aşağıda tablolar ile belirtilmektedir.

Hipotez 1: Konum riski negatif inovasyon algısı ile dönüştürücü liderlik ile negatif yönde(H1a) ve etkileşimci liderlik ile pozitifyönde (H1b) bir ilişki vardır.

Tablo 4. Hipotez 1’e Yönelik Korelasyon Analizi

\begin{tabular}{|c|c|c|c|}
\hline \multicolumn{2}{|c|}{ Liderlik Tarzı } & $\begin{array}{l}\text { Dönüştürüicü } \\
\text { Liderlik }\end{array}$ & $\begin{array}{l}\text { Etkileşimci } \\
\text { Liderlik }\end{array}$ \\
\hline \multirow{3}{*}{$\begin{array}{c}\text { Konum Riski } \\
\text { Negatif } \\
\text { İnovasyon } \\
\text { Algısı }\end{array}$} & $\begin{array}{c}\text { Korelâsyon } \\
\text { Katsayis1 } \\
\end{array}$ & .028 & $.308^{* *}$ \\
\hline & $\begin{array}{c}\text { Sig. } \\
\text { (2-kuyruklu) }\end{array}$ & .775 & .001 \\
\hline & Kişi & 108 & 108 \\
\hline
\end{tabular}

*Korelâsyon 0.05 düzeyinde anlamlıdır **Korelâsyon 0.01 düzeyinde anlamlıdır.

Araştırmaya katılan işletme sahibi ve yöneticilerinin konum riskinden kaynaklanan negatif inovasyon algısı ile liderlik tarzı arasındaki ilişkinin test edildiği korelâsyon analizi sonucunda, etkileşimci liderlik tarzını benimseyen katılımc1lar ile konum riskinden kaynaklanan negatif inovasyon algisı arasında 0.308 oranında istatistiksel olarak pozitif yönlü ve anlamlı derecede ilişki olduğu tespit edilmiştir. Etkileşimci liderliğe yönelik artış, konum riskinden kaynaklanan negatif inovasyon algısında \%30. 8 düzeyinde artışa neden olmaktadır. Dönüştürücü liderlik tarzı ile konum riskinden kaynaklanan negatif inovasyon algısı arasında istatistiksel olarak anlamlı bir ilişki tespit edilememiştir. Hipotez 1'e yönelik yapılan korelâsyon analizi sonucunda H1a RED edilirken, H1b KABUL edilmektedir. 
Hipotez 2: İnovasyonu yönetememe algısı ile dönüştürücü liderlik ile negatif yönde(H2a) ve etkileşimci liderlik ile pozitif yönde (H2b) bir ilişsi vardır.

Tablo 5. Hipotez 2’ye Yönelik Korelâsyon Analizi

\begin{tabular}{|c|c|c|c|}
\hline \multicolumn{2}{|c|}{ Liderlik Tarzı } & $\begin{array}{c}\text { Dönüştürücü } \\
\text { Liderlik }\end{array}$ & $\begin{array}{l}\text { Etkileşimci } \\
\text { Liderlik }\end{array}$ \\
\hline \multirow{3}{*}{$\begin{array}{c}\text { İnovasyonu } \\
\text { Yönetememe } \\
\text { Algısı }\end{array}$} & $\begin{array}{l}\text { Korelâsyon } \\
\text { Katsay1s1 }\end{array}$ & -.030 & .104 \\
\hline & $\begin{array}{c}\text { Sig. } \\
\text { (2-kuyruklu) }\end{array}$ & .760 & .284 \\
\hline & Kişi & 108 & 108 \\
\hline
\end{tabular}

*Korelâsyon 0.05 düzeyinde anlamlıdır **Korelâsyon 0.01 düzeyinde anlamlidir.

Araştırmaya katılan işletme sahibi ve yöneticilerinin inovasyonu yönetememe endişesinden kaynaklanan negatif inovasyon algıları ile dönüştürücü ve etkileşimci liderlik tarzları arasında istatistiksel olarak anlamlı derecede bir ilişki tespit edilememiş̧tir. Hipotez 2' ye yönelik yapılan korelâsyon analizi sonucunda $\mathrm{H} 2 \mathrm{a}$ ve $\mathrm{H} 2 \mathrm{~b}$ RED edilmiştir.

Hipotez 3: Belirsizlikten kaynaklanan negatif inovasyon algısı ile dönüştürücü liderlik ile negatif yönde( $\mathrm{H} 3 \mathrm{a}$ ) ve etkileşimci liderlik ile pozitif yönde (H3b) bir ilişki vardır.

Tablo 6. Hipotez 3’e Yönelik Korelâsyon Analizi

\begin{tabular}{|c|c|c|c|}
\hline \multicolumn{2}{|c|}{ Liderlik Tarzı } & $\begin{array}{l}\text { Dönüştürücü } \\
\text { Liderlik }\end{array}$ & $\begin{array}{l}\text { Etkileşimci } \\
\text { Liderlik }\end{array}$ \\
\hline \multirow{3}{*}{$\begin{array}{c}\text { Belirsizlikten } \\
\text { Kaynaklanan } \\
\text { Negatif } \\
\text { İnovasyon Algısı }\end{array}$} & $\begin{array}{c}\text { Korelâsyon } \\
\text { Katsay1s1 } \\
\end{array}$ & $-.376^{* *}$ & .141 \\
\hline & $\begin{array}{c}\text { Sig. } \\
\text { (2-kuyruklu) }\end{array}$ & .000 & .147 \\
\hline & Kiși & 108 & 108 \\
\hline
\end{tabular}

*Korelâsyon 0.05 düzeyinde anlamlıdır **Korelâsyon 0.01 düzeyinde anlamlidir. 
Katılımcıların inovasyonun belirsizlik getireceğine ilişkin düşüncelerinden kaynaklanan negatif inovasyon algıları ile dönüştürücü liderlik tarzı arasında istatistiksel olarak anlamlı ve negatif yönde 0.376 oranında ilişki olduğu tespit edilmiştir. İşletme sahibi ve yöneticilerinin dönüştürücü liderliğe yönelik uygulamaları neticesinde, belirsizlikten kaynaklanan negatif inovasyon algısında \%37. 6 düzeyinde bir azalma görülmektedir. Etkileşimci liderlik tarzı ile belirsizlikten kaynaklanan negatif inovasyon algısı arasında istatistiksel olarak anlamlı bir ilişki tespit edilememiştir. Hipotez 3'e yönelik yapılan korelâsyon analizi sonucunda H3a KABUL edilirken, H3b RED edilmektedir.

Hipotez 4: Inovasyonun ek maliyet getireceği algısı ile dönüştürücü liderlik ile negatif yönde(H4a) ve etkileşimci liderlik ile pozitif yönde (H4b) bir ilişki vardir.

Tablo 7. Hipotez 4’e Yönelik Korelâsyon Analizi

\begin{tabular}{||c|c|c||c||}
\hline \multicolumn{2}{|c|}{ Liderlik Tarzı } & $\begin{array}{c}\text { Dönüşstürücü } \\
\text { Liderlik } \\
\text { (H4a) }\end{array}$ & $\begin{array}{c}\text { Etkileşimci } \\
\text { Liderlik } \\
\text { (H4b) }\end{array}$ \\
\hline \hline \multirow{4}{*}{$\begin{array}{c}\text { İnovasyonun Ek } \\
\text { Maliyet } \\
\text { Getireceği Algısı }\end{array}$} & $\begin{array}{c}\text { Korelâsyon } \\
\text { Katsayısı }\end{array}$ & -.097 & $.554^{* *}$ \\
\cline { 2 - 4 } & $\begin{array}{c}\text { Sig. } \\
\text { (2-kuyruklu) }\end{array}$ & .317 & .000 \\
\cline { 2 - 4 } & Kişi & 108 & 108 \\
\hline
\end{tabular}

*Korelâsyon 0.05 düzeyinde anlamlıdır **Korelâsyon 0.01 düzeyinde anlamlidir.

Araştırmaya katılan işletme sahibi ve yöneticilerinin, inovasyonun işletmeye ek maliyet getireceğine yönelik negatif inovasyon algısı ile liderlik tarzı arasındaki ilişki korelâsyon analizi ile test edilmiştir. Korelâsyon analizi sonucunda, etkileşimci liderlik tarzını benimseyen katılımcılar ile inovasyonun işletmeye ek maliyet getireceğine yönelik algıları arasında 0.554 oranında istatistiksel olarak anlamlı derecede ve pozitif yönlü ilişki olduğu tespit edilmiştir. Etkileşimci liderliğe yönelik artış, inovasyonun ek maliyet getireceğine yönelik negatif inovasyon algısında \%55. 4 düzeyinde artışa neden olmaktadır. Dönüştürücü liderlik tarzı ile inovasyonun ek maliyet getireceğine yönelik negatif inovasyon algısı arasında istatistiksel olarak anlamlı bir ilişki tespit edilememiştir. Hipotez 4'e yönelik yapılan korelâsyon analizi sonucunda H4a RED edilirken, H4b KABUL edilmektedir. 
Hipotez 5: İnovasyonun köklü değişikliğe sebep olacağı algısı ile dönüşürü̈cü liderlik ile negatif yönde( $H 5 a)$ ve etkileşimci liderlik ile pozitif yönde (H5b) bir ilişsi vardır.

Tablo 8. Hipotez 5’e Yönelik Korelâsyon Analizi

\begin{tabular}{|c|c|c|c|}
\hline \multicolumn{2}{|c|}{ Liderlik Tarzı } & $\begin{array}{l}\text { Dönüştürücü } \\
\text { Liderlik }\end{array}$ & $\begin{array}{l}\text { Etkileşimci } \\
\text { Liderlik }\end{array}$ \\
\hline \multirow{3}{*}{$\begin{array}{l}\text { İnovasyonun } \\
\text { Köklü } \\
\text { Değişikliğe } \\
\text { Sebep Olacağı } \\
\text { Algısı }\end{array}$} & $\begin{array}{c}\text { Korelâsyon } \\
\text { Katsay1s1 } \\
\end{array}$ & -.165 & .098 \\
\hline & $\begin{array}{c}\text { Sig. } \\
\text { (2-kuyruklu) }\end{array}$ & .088 & .311 \\
\hline & Kişi & 108 & 108 \\
\hline
\end{tabular}

*Korelâsyon 0.05 düzeyinde anlamlıdır **Korelâsyon 0.01 düzeyinde anlamlıdır.

Katılımcıların inovasyonun köklü değişikliğe sebep olacağına yönelik düşüncelerinden kaynaklanan negatif inovasyon algıları ile dönüştürücü ve etkileşimci liderlik tarzları arasında istatistiksel olarak anlamlı bir ilişki tespit edilememiş̧tir. Hipotez 5' e yönelik yapılan korelâsyon analizi sonucunda H5a ve H5b RED edilmiştir.

Hipotez 6: Müşteri direnci negatif inovasyon algisı ile dönüşürrücü liderlik ile negatifyönde(H6a) ve etkileşimci liderlik ile pozitif yönde (H6b) bir ilişki vardır.

Tablo 9. Hipotez 6’ya Yönelik Korelâsyon Analizi

\begin{tabular}{|c|c|c|c|}
\hline \multicolumn{2}{|c|}{ Liderlik Tarzı } & $\begin{array}{l}\text { Dönüştürücü } \\
\text { Liderlik }\end{array}$ & $\begin{array}{l}\text { Etkileşimci } \\
\text { Liderlik }\end{array}$ \\
\hline \multirow{3}{*}{$\begin{array}{c}\text { Müşseri Direnci ile } \\
\text { Karşılaşılacağı } \\
\text { Algısı }\end{array}$} & $\begin{array}{c}\text { Korelâsyon } \\
\text { Katsay1s1 }\end{array}$ & $-.535^{* *}$ & $.277^{* *}$ \\
\hline & $\begin{array}{c}\text { Sig. } \\
\text { (2-kuyruklu) }\end{array}$ & .000 & .004 \\
\hline & Kişi & 108 & 108 \\
\hline
\end{tabular}

*Korelâsyon 0.05 düzeyinde anlamlıdır **Korelâsyon 0.01 düzeyinde anlamlidir. 
Araştırmaya katılan işletme sahibi ve yöneticilerinin, müşteri direnci ile karşılaşılabileceğine yönelik negatif inovasyon algıları ile dönüştürücü ve etkileşimci liderlik tarzları arasında istatistiksel olarak anlamlı ilişkiler olduğu tespit edilmiştir. Dönüştürücü liderlik tarzı ile müşteri direnci ile karşılaşılacağına yönelik olumsuz inovasyon algısı arasında negatif yönlü ve anlamlı 0.535 düzeyinde bir ilişki olduğu tespit edilmiştir. Dönüştürücü liderlik tarzına yönelik uygulamalar arttıkça, müşteri direnci ile karşıllaşılacağına yönelik negatif inovasyon algısında \%53. 5 düzeyinde bir azalma olacağı tespit edilmiştir. Etkileşimci liderlik tarzı ile müş̧teri direnci ile karşılaşılacağına yönelik olumsuz inovasyon algısı arasında istatistiksel olarak anlamlı ve pozitif yönde 0.277 düzeyinde bir ilişki olduğu belirlenmiştir. Etkileşimci liderlik tarzına yönelik uygulamalar arttıkça, müşteri direnci ile karşılaşılacağına yönelik olumsuz inovasyon algısında \%22. 7 oranında artış olacağı tespit edilmiş̧ir. Hipotez 6' ya yönelik yapılan korelasyon analizi sonucunda H6a ve H6b KABUL edilmektedir.

Hipotez 7: Personel direnci negatif inovasyon algisı ile dönüştürücü liderlik ile negatif yönde(H7a) ve etkileşimci liderlik ile pozitif yönde (H7b) bir ilişsk vardir.

Tablo 10. Hipotez 7’ye Yönelik Korelâsyon Analizi

\begin{tabular}{|c|c|c|c|}
\hline \multicolumn{2}{|c|}{ Liderlik Tarzı } & \multirow{2}{*}{$\begin{array}{c}\begin{array}{c}\text { Dönüştürücü } \\
\text { Liderlik } \\
\text { (H7a) }\end{array} \\
096\end{array}$} & \multirow{2}{*}{$\begin{array}{c}\begin{array}{c}\text { Etkileşimci } \\
\text { Liderlik } \\
(\text { H7b) }\end{array} \\
.441^{* *}\end{array}$} \\
\hline \multirow{3}{*}{$\begin{array}{c}\text { Personel } \\
\text { Direnci ile } \\
\text { Karşılaşılacağı } \\
\text { Algısı }\end{array}$} & $\begin{array}{c}\text { Korelâsyon } \\
\text { Katsay1s1 } \\
\end{array}$ & & \\
\hline & $\begin{array}{c}\text { Sig. } \\
\text { (2-kuyruklu) }\end{array}$ & .321 & .000 \\
\hline & Kişi & 108 & 108 \\
\hline
\end{tabular}

Araştırmaya katılan işletme sahibi ve yöneticilerinin, inovasyon uygulamalarının personel direnci ile karşılaşılacağına yönelik negatif inovasyon algısı ile liderlik tarzı arasındaki ilişki korelâsyon analizi ile test edilmiştir. Korelâsyon analizi sonucunda, etkileşimci liderlik tarzını benimseyen katılımcılar ile inovasyonun personel tarafından dirençle karşılaşılacağına yönelik algıları arasında 0.441 oranında istatistiksel olarak anlamlı derecede ve pozitif yönlü ilişki olduğu tespit edilmiştir. Etkileşimci liderliğe yönelik artış, inovasyon uygulamalarının personel tarafından dirençle karşılaşılacağı algısında \%44. 1 düzeyinde artışa neden olmaktadır. Dönüştürücü liderlik tarzı ile 
inovasyon uygulamalarının personel direnci ile karşılaşılacağına yönelik negatif inovasyon algısı arasında istatistiksel olarak anlamlı bir ilişki tespit edilememiştir. Hipotez 7'ye yönelik yapılan korelâsyon analizi sonucunda H7a RED edilirken, H7b KABUL edilmektedir.

\section{DEĞERLENDIRME VE SONUÇ}

İnovasyon ile ilgili yapılacak yenilikler ve değişiklikler beraberinde belirsizlikleri de getirmektedir. $\mathrm{Bu}$ durum, çalışanların değişikliklere direnç göstermesine yol açabileceği gibi, yöneticiler ve işletme sahipleri açısından da olumsuz sonuçlara yol açabileceği düşüncesi ile negatif olarak algılanabilmektedir. Bu çalışmada işletme sahipleri ve yöneticilerinin negatif inovasyon algıları ile dönüştürücü ve etkileşimci liderlik uygulamaları arasındaki ilişkiyi ortaya koymaya çalışmaktadır.

$\mathrm{Bu}$ amaçla yapılan alan araştırması sonucunda elde edilen veriler tanımlayıcı istatistik analizi ve korelâsyon analizi ile değerlendirilmeye çalışılmıştır. Negatif inovasyon algısına yönelik yapılan tanımlayıcı istatistik analizi sonuçlarına göre, en yüksek negatif inovasyon algıları; belirsizlik algısı, köklü değişiklik algısı ve inovasyonu yönetememe algısıdır. Araştırmaya katılan işletme sahiplerinin ve yöneticilerinin, inovasyona yönelik negatif algılarının çok yüksek olmadığı, ortalamaya yakın ya da ortalamanın biraz üzerinde olduğu görülmektedir. İşletme sahipleri ve yöneticilerin uyguladıkları liderlik tarzlarına yönelik tanımlayıcı istatistik analizleri incelendiğinde ise, dönüştürücü liderlik tarzının ortalamanın epey üzerinde olduğu sonucuna ulaşılmıştır.

Negatif inovasyon algıları ile dönüştürücü ve etkileşimci liderlik tarzları arasındaki ilişkiyi tespit etmeye yönelik yapılan korelasyon analizi sonucunda istatistiksel olarak anlamlı neticeler elde edilmiştir. İnovasyon uygulamaları sonucunda, yöneticilerin mevcut konumlarını koruyamayacakları düşüncesi ile etkileşimci liderlik arasında anlamlı ilişki tespit edilmiştir. Etkileşimci liderlik tarzının, yöneticilerin konumlarını kaybedeceği düşüncesinde artışa neden olduğu tespit edilmiştir.

İşletme sahipleri ve yöneticilerinin inovasyonu yönetemeyeceklerine dair negatif algıları ile dönüştürücü ve etkileşimci liderlik tarzları arasında anlamlı bir ilişkiye rastlanmamıştır. Dönüştürücü liderlik tarzı uygulamalarının belirsizlikten kaynaklanan negatif inovasyon algısını azaltıcı etkisi olduğu görülmektedir. Etkileşimci liderlik tarzını benimseyen yöneticilerin, inovasyonun ek maliyet getireceği algısında da artış meydana gelmektedir. İnovasyonun köklü değişikliğe neden olacağ düşüncesi ile endişelenen yöneticilerin uyguladıkları dönüştürücü ve etkileşimci liderlik tarzları arasında anlamlı bir ilişki bulunamamıştır. 
İnovasyon uygulamaları sonucunda müşterilerin direnci ile karşılaşılacağ algısı, dönüştürücü liderlik tarzı ile ters orantılı iken, etkileşimci liderlik tarzı ile doğru orantılıdır. Etkileşimci liderlik tarzı uygulamaları, müşteri direnci ile karşılaşma algısını artırmakta, dönüştürücü liderlik tarzı uygulamaları ise azaltmaktadır. Etkileşimci liderlik tarzını benimseyen yöneticilerin, bu liderlik tarzına yönelik uygulamaları arttıkça, inovasyon uygulamaları neticesinde personel direnci ile karşılaşacaklarına dair algılarında da artış görülmektedir. Torun (2006: 94) tarafindan yapılan benzer bir araştırmada, dönüştürücü liderlik tarzı uygulamalarının müşteri direnci algısından etkilendiği sonucu ortaya çıkmıştır.

Sonuç olarak, dönüştürücü liderlik tarzının negatif inovasyon algılarını azaltma yönünde ilişkili olduğu görülürken, etkileşimci liderlik tarzı uygulamalarının ise negatif inovasyon algılarının artmasına neden olduğu tespit edilmiştir. Sonraki çalışmalara öneri olarak, inovasyon uygulamaları sonucunda ortaya çıkan olumlu ve olumsuz inovasyon algılarının tüm liderlik tarzları ile ilişkisinin araştırılması öneri olarak sunulabilir. Ayrıca konunun sektörel olarak karşılaştırılması ve daha geniş ölçekte araştırılmasının literatüre katkı sunacağ 1 düşünülmektedir.

\section{KAYNAKLAR}

Ashkarran, Ali Akbar; Sadegh, Rezaei ve Chehrazi, Roshanak (2015). "Impact of Transformational and Transactional Leadership Style on Employees' Creativity and Innovation”. International Journal of Environmental Research, 12 (4), ss. 1109-1123.

Antonakis, John; Avolio, Bruce, J. ve Sivasubramaniam, Nagaraj (2003). "Context and Leadership: An Examination of The Nine-Factor FullRange Leadership Theory Using The Multifactor Leadership Questionnaire”. The Leadership Quarterly, 14 (3), ss. 261-295.

Baregheh, Anahita; Rowley Jennifer ve Rambrook Sally (2009). “Towards A Multidisciplinary Definition of Innovation”. Management Decision. 47 (8), ss. 1323-1339.

Bass, Bernard, M. (1985). “Leadership: Good, Better, Best”. Organizational Dynamics, 13 (3), ss. 26-40.

Bass, Bernard, M. ve Bass, Ruth (2008). Handbook of Leadership: Theory, Research, and Application.Free Press, New York. 
Dinçer, Müjde Ker ve Bitirim, Selin (2007). "Kurum Kültürü Çalışmalarında Hizmetkâr Liderlik Anlayışı ile Değer Yaratmak". İstanbul Üniversitesi İletişim Fakültesi Dergisi, 28, ss. 61-72.

Eren, Erol (2003). Yönetim ve Organizasyon (Çağdaş ve Küresel Yaklaşımlar). 6. Baskı, Beta Yayınları, İstanbul.

Fernandes, Cedwyn ve Awamleh, Raed (2004). “The Impact of Transformational and Transactional Leadership Styles on Employee's Satisfaction and Performance: An Empirical Test in A Multicultural Environment”, International Business and Economics Research, 3(8), ss. 65-76.

Gamal, Dalia; Salah, Eng Tarek ve Elrayyes Nesreen (2011). “How to Measure Organization Innovativeness?: An Overview of Innovation Measurement Frameworks and Innovative Audit/ Management Tools”, Technology Innovation and Entrepreneurship Center, Egypt Innovate, ss. 1-35.

Garcia Morales, Victor J.; Matias; Reche, Fernando ve Hurtado Torres, Nuria (2008). "Influence of Transformational Leadership on Organizational Innovation and Performance Depending on The Level of Organizational Learning in The Pharmaceutical Sector”. Journal of Organizational Change Management, 21 (2), ss. 188-212.

Gardner, William L. ve Avolio, Bruce J. (1998). "The Charismatic Relationship: A Dramaturgical Perspective”. Academy of Management Review, 23 (1), ss. 32-58.

Gürel, Gözde (2011). Örgütsel Öğrenme, Dönüşümcü liderlik, Pazar Yönlendirmesi ve Örgütsel İnovasyonun Firma Performansı Üzerine Etkilerinin Analizi, (Yüksek Lisans Tezi), İstanbul Üniversitesi, Sosyal Bilimler Enstitüsü, İstanbul.

Hussain, Syed, Talib; Abbas, Jaffar; Lei, Shen; Jamal Haider, Muhammad ve Akram, Tayyaba (2017). “Transactional Leadership and Organizational Creativity: Examining The Mediating Role of Knowledge Sharing Behavior”. Cogent Business \& Management, 4 (1), ss. $1-11$.

Jung, Dongil Don.- Wu, Anne - Chow, Chee W. (2008). "Towards Understanding The Direct and Indirect Effects of CEOs' Transformational Leadership on Firm Innovation”. The Leadership Quarterly, 19 (5), ss. 582-594. 
Jung, Dongil Don.; Chow, Chee W. ve Wu, Anne (2003). "The Role of Transformational Leadership in Enhancing Organizational Innovation: Hypotheses and Some Preliminary Findings". The Leadership Quarterly, 14(4-5), ss. 525-544.

Kalaycı, Şeref (2008), SPSS Uygulamalı Çok Değişkenli İstatistik Teknikleri, (3.Baskı), Asil Yayın Dağıtım, Ankara.

Kılıç, Recep; Keklik, Belma ve Yıldız, Harun (2014). “Dönüşsürücü, Etkileşimci ve Tam Serbesti Tanıyan Liderlik Tarzlarının Örgütsel Sessizlik Üzerindeki Etkisini Belirlemeye Yönelik Bir Araştırma”. Yönetim ve Ekonomi Dergisi, 21(2), ss. 249-268.

Koçel, Tamer (2014). İşletme Yöneticiliği (Genişletilmiş 15. Bask1), Beta Yayınları, İstanbul.

Koparal, Celil (2007). Yönetim Organizasyon (Vol. 774), Anadolu Üniversitesi, Anadolu Üniversitesi Yayınları, Eskişehir.

Mumford, Michael D.; Zaccaro, Stephen J.; Harding, Francis, D.; Jacobs, T. Owen ve Fleishman, Edwin, A. (2000). "Leadership Skills for A Changing World: Solving Complex Social Problems”. The Leadership Quarterly, 11(1), ss. 11-35.

Nielsen, Karina ve Cleal, Bryan (2011). “Under Which Conditions Do Middle Managers Exhibit Transformational Leadership Behaviors?-An Experience Sampling Method Study on The Predictors of Transformational Leadership Behaviors”. The Leadership Quarterly, 22(2), ss. 344-352.

Odumeru, James, A. ve Ogbonna, Ifeanyi, George (2013). “Transformational vs. Transactional Leadership Theories: Evidence in Literature”. International Review of Management and Business Research, 2(2), ss. 355-361.

Örücü, Edip; Kılıç, Recep ve Savaş, Abdullah (2011). “KOBİ'lerde İnovasyon Stratejileri ve İnovasyon Yapmayı Etkileyen Faktörler: Bir Uygulama”, Doğuş Üniversitesi Dergisi, 12(1), ss. 58-73.

Schein, Edgar, H. (2004). Organizational Culture and Leadership, Third Edition, John Wiley \& Sons Inc, San Francisco.

Senge, Peter, M.; Roberts, Charlotte; Ross, Rick, B.; Smith, Brian, J. ve Kleiner, Alexander (1994). The Fifth Discipline Fieldbook, Bantam Doubleday Dell, New York. 
Simpson, Penny, M.; Siguaw, Judy, A. ve Enz, Cathy, A. (2006). “Innovation Orientation Outcomes: The Good and The Bad”. Journal of Business Research, 59(10-11), ss. 1133-1141.

Torun, Burak (2016). İnovasyon Algısı, İnovasyon Sürecindeki Liderlik Tarzları ve İşletmenin İnovasyon Performansı Arasındaki İlişkiler: Düzce'deki Kobi'ler Üzerinde Bir Araştırma, (Yüksek Lisans Tezi),: Düzce Üniversitesi, Sosyal Bilimler Enstitüsü, Düzce.

Turner, Nick; Barling, Julian ve Zacharatos, Anthea (2002). "Positive Psychology at Work”. Handbook of Positive Psychology, 52, ss. 715728.

Zaccaro, Stephen, J.; Mumford, Michael, D.; Connelly, Shane; Marks, Michelle, A. ve Gilbert, Jack, A. (2000). “Assessment of Leader ProblemSolving Capabilities”. The Leadership Quarterly, 11(1), ss. 37-64.

Zeleny, Milan (2012). "High Technological Barriers to Innovation". International Journal of Information Technology, 11(2), ss. 441-456. 